\title{
Pemanfaatan kelas ibu hamil dan aplikasi grup pesan pintar sebagai sarana edukasi kehamilan
}

\author{
Wilda Rezki Pratiwi, Nurjanna*
}

Program Studi DIII Kebidanan STIKES Muhammadiyah Sidrap.”Email: noorjannaharunaaz@gmail.com

\author{
Abstract \\ Information giving and education in pregnancy using a traditional classroom and an online education \\ (group messaging apps)
}

Background: The efforts to improve health during pregnancy are by using a traditional classes facility to provide knowledge and information on health during pregnancy. Most community has not known some online applications that can use at positive things as suggestions for learning or health education purposes. Researchers want to innovate with social media users: WhatsApp groups to provide information and knowledge.

Purpose: To analyze the differences in knowledge, activeness, motivation and behavior when information and education in pregnancy using a traditional classroom and an online education (group messaging apps).

Method: Quantitative research with the design method of quasi-experiment by pretest-posttest divided in two groups. The population was Pregnant women's with the sample of 30 participants comprising 15 participants in the control group and 15 participants in the intervention group. Location in Sidenreng Rappang regency, south Sulawesi province, Indonesia.

Results: In an online education (group messaging apps) group, the variables of knowledge, activeness, motivation and action influence the use of the class of pregnant women and WhatsApp media to educate problems around pregnancy, while in the control group the results of the variables of knowledge, activeness, and motivation influence class utilization pregnant women to educate problems. Meanwhile, the action variable has no effect.In order to further increase the campaign on the importance of the participation of pregnant women in implementing pregnant women classes and be able to do it regularly by involving cadres and their families

Keywords: Information giving; Education; Pregnancy; Traditional classroom; Online education (group messaging apps)

Pendahuluan : Salah satu upaya pemerintah yaitu pemberdayaan masyarakat dengan penyelenggaraan kelas ibu hamil. Fenomena masyarakat saat ini menganggap media sosial berpengaruh negative. Namun jika pemanfaatan media sosial diarahkan kehal yang positif seperti halnya penelitian ini ingin membuat inovasi dengan pemanfaat media sosial yaitu membuat group whatsapp sebagai sarana informasi, pelayanan kepada masyarakat. sehingga akan sangat besar manfaatnya kepada masyarakat khususnya ibu hamil.

Tujuan: Menganalisa perbedaaan pengetahuan, keaktifan, motivasi dan tindakan ibu pada kelompok kelas ibu hamil dan aplikasi media whatsapp

Metode: Penelitian kuantitatif dengan metode desain quasi experiment dengan rancangan penelitian pretestposttest two group design. Populasinya para ibu hamil dengan sampel 30 partisipan yang dibagi 2 kelompok terdiri dari 15 partisipan pada kelompok kontrol dan 15 partisipan pada kelompok intervensi. Lokasi di Kabupaten Sidenreng Rappang, Provinsi Sulawesi Selatan, Indonesia.

Hasil : Pada kelompok kasus didapatakan hasil variabel pengetahuan, keaktifan, motivasi dan tindakan berpengaruh terhadap pemanfaatan kelas ibu hamil dan media whatsapp sebagai sarana edukasi masalah seputar kehamilan, sedangkan pada kelompok kontrol didapatakan hasil variabel pengetahuan, keaktifan , dan motivasi berpengaruh terhadap pemanfaatan kelas ibu hamil sebagai sarana edukasi masalah seputar kehamilan.

Kata Kunci : Pemanfaatan; Kelas ibu hamil; Aplikasi grup pesan pintar; Edukasi kehamilan 


\section{PENDAHULUAN}

Sustainable Development Goals (SDGs) merupakan kelanjutan dari Millenium Development Goals (MDGs). Salah satu prioritas target SDGs adalah pilar pembangunan sosial yaitu derajat kesehatan dan kesejahteraan dengan target menjamin kehidupan yang sehat dan mendorong kesejahteraan bagi semua orang di segala usia yaitu pada 2030 mengurangi AKI hingga di bawah 70 per $100.000 \mathrm{KH}$ (Sutopo, Arthati \& Rahmi,2014 ). Program pembangunan kesehatan di Indonesia masih diprioritaskan pada upaya peningkatan derajat kesehatan ibu dan anak yaitu ibu hamil, bersalin dan bayi (Simorangkir, \& Sumardiani, 2016).

Data AKI di Indonesia pada tahun 2012 yaitu 359/100.000 KH (Kelahiran Hidup). Penyebabnya yaitu perdarahan, hipertensi, infeksi, partus lama, abortus, dimana penyebab terbesar kematian ibu selama tahun 2012-2013 yaitu perdarahan (Kementerian Kesehatan Republik Indonesia, 2014)

Untuk mencegah hal tersebut salah satu upaya pemerintah yaitu pemberdayaan masyarakat dengan penyelenggaraan kelas ibu hamil. Kelas ibu hamil bertujuan untuk meningkatkan pengetahuan dan keterampilan ibu mengenai kehamilan, persalian, perawatan nifas, keluarga berencana, perawatan bayi baru lahir dan senam hamil (Setyaningsih, \& Ersila, 2016). Indonesia sejak tahun 2009 sudah menerapkan metode pembelajaran kelas ibu hamil. Kebijakan ini dilakukan karena masih adanya kasus-kasus komplikasi maternal yang terjadi dan angka kematian ibu yang masih tinggi (Baroroh, Jannah, \& Meikawati, 2017).

Penelitian yang dilakukan Oktaviance pada 132 ibu hamil 69 ibu hamil yang pernah mengikuti kelas ibu hamil dan 63 yang tidak pernah mengikuti kelas ibu hamil menyimpulkan bahwa ibu yang pernah mengikuti kelas ibu hamil memiliki pengetahuan dan sikap lebih baik dari ibu yang tidak pernah mengikuti kelas ibu hamil yaitu nilai $p<0.001$. Menurut hasil pengamatan peneliti, rata-rata sikap responden yang pernah mengikuti kelas ibu hamil lebih besar dari responden yang tidak pernah mengikuti kelas ibu hamil, sama halnya dengan rata-rata pengetahuan responden yang pernah mengikuti kelas ibu hamil lebih besar dari yang tidak pernah mengikuti kelas ibu hamil (Simorangkir, \& Sumardiani, 2016)

Berdasarkan laporan Asosiasi Penyelenggara Jaringan Internet Indonesia mengenai survei Penetrasi dan perilaku pengguna internet
Indonesia pada tahun 2017, pengguna internet berdasarkan jenis kelamin 48,57\% perempuan dan $51,43 \%$ adalah laki-laki. Sedangkan menurut We Are Social pengguna aktif platform media sosial di Indonesia, salah satunya pengguna Instagram sebanyak $38 \%$ dan merupakan 4 besar media sosial yang digunakan di Indonesia setelah Youtube, Facebook dan WhatsApp (Widarini, 2019)

Dampak dari perkembangan dunia teknologi informasi dan komunikasi pada saat ini peningkatan akses terhadap internet mulai mengubah gaya hidup manusia dalam berbagai aspek, baik itu di dalam bidang ekonomi, politik, hingga kehidupan sosial masyarakat saat ini sudah diwarnai dengan kecanggihan dunia teknologi informasi dan komunikasi (Mandiri, 2016). Manusia saling berkomunikasi dengan lawan bicara yang berada pada jarak yang jauh dengan begitu mudah.

Maka perlu adanya inovasi untuk membuat group media sosial whatsapp. Dimana dinamika kehidupan masyarakat mengalami perkembangan yang sangat pesat. Akulturasi budaya dengan sentuhan teknologi informasi merupakan fenomena pendorong perubahan dan WhatsApp dapat menjadi media peningkatan edukasi kesehatan berbasis media sosial merupakan fasilitas komunikasi antara educator kesehatan dan learner dengan sistem diskusi (Ekadinata, \& Widyandana, 2017; Cahyono, 2016).

Fenomena masyarakat saat ini menganggap media sosial berpengaruh negative. Namun jika pemanfaatan media sosial diarahkan kehal yang positif seperti halnya penelitian ini ingin membuat inovasi dengan pemanfaat media sosial yaitu membuat group whatsapp sebagai sarana informasi, pelayanan kepada masyarakat. sehingga akan sangat besar manfaatnya kepada masyarakat khususnya ibu hamil.

Penggunaan Aplikasi Sayangi lbuku berbasis android dan dapat digunakan untuk mencari informasi seputar kesehatan reproduksi remaja, persiapan kehamilan, menjaga kehamilan dan informasi umum terkait kesehatan ibu dan anak. Aplikasi Sayangi lbuku sangat bermanfaat untuk meningkatkan pengetahuan ibu dan keluarganya terkait kehamilan sehat dan aman guna melahirkan generasi penerus yang lebih baik (Nursanti, \& Ayusafitri, 2019).

Penelitian dengan judul pengaruh edukasi melalui media whatsapp terhadap pengetahuan ibu dalam memberikan asi eksklusif ibu menyusui di wilayah kerja puskesmas wonosobo 
Pemanfaatan kelas ibu hamil dan aplikasi grup pesan pintar sebagai sarana edukasi kehamilan

memperlihatkan peningkatan pengetahuan dalam memberikan asi eksklusif setelah diberikan edukasi melalui whatsapp. meskipun demikian tidak ada perbedaan pengetahuan yang signifikan pada kelompok whatsapp maupun pada kelompok booklet setelah edukasi (Yani, \& Suriah, 2017).

Jumlah ibu hamil di wilayah kerja Puskesmas

Empagae Kabupaten Sidrap pada tahun 2018 sebanyak 395 orang sedangkan tahun 2019 sebayak 388 orang. Sedangkan jumlah ibu hamil pada bulan Januari - Juni 2020 di desa Mojong sebanyak 68 orang. Berdasarkan hasil studi pendahuluan yang dilakukan oleh peneliti di temukan fakta bahwa pelaksanaan kelas ibu hamil di Desa Mojong Kabupaten Sidrap sudah dilakukan setiap bulannya namun masih terdapat ibu hamil yang sering tidak mengikuti kelas ibu hamil karena kesibukan masing-masing dan kurangnya minat ibu hamil untuk memprioritaskan waktu mengikuti kelas ibu hamil. Penggunaan media sosial khususnya grup whatsapp tidak menjadi alternative pilihan untuk ibu - ibu hamil melakukan komunikasi berbagi pengalaman dan ilmu sehinggah dipandang perlu membuat group Whatsapp kelas ibu hamil sehingga peneliti tertarik untuk meneliti tentang pengaruh pemanfaatan kelas ibu hamil dan aplikasi media whatsapp sebagai sarana eduksi masalah seputar kehamilan di kabupaten Sidrap.

\section{METODE PENELITIAN}

Penelitian quasi experiment dengan rancangan penelitian the pretest- posttest two group design.
Lokasi penelitian di lakukan di Desa Mojong Kecamatan Wattang Sidenreng Kabupaten Sidrap pada bulan Juni s/d Agustus 2020. Populasi ibu hamil yang usia kehamilannya > 24 Minggu. Sampel sebanyak 30 ibu hamil yang dibagi menjadi 2 kelompok kasus dan kontrol. Tekhnik pengambilan sampel yaitu sampling nonprobabilitas yaitu sampling purpossive dengan kriteria inklusi dan esklusi. Pengumpulan data dilakukan melalui wawancara langsung dengan ibu hamil pada saat pelaksanaan kelas ibu hamil, pengisian kuisioner melalui geogle font dan evaluasi pada aplikasi media whatsapp selama 3 bulan. Jumlah kuisioner pengetahuan terdiri dari 15 pertanyaan dengan alternatif jawaban skor tertinggi 1 dan terendah 0 dengan hasil ukur baik jika nilainya $\geq 76-100 \%$, cukup jik $60-75 \%$ dan kurang jika $<60 \%$, keaktifan terdiri dari 2 pertanyaan yaitu aktif jika responden mengikuti kelas ibu hamil $\geq 3 \times$ dan tidak aktif jika responden mengikuti kelas ibu hamil $\leq 3$, Motivasi terdiri dari 10 pertanyaan, motivasi tinggi jika $\geq 60-100$ dan motivasi rendah jika $<60$ sedangkan tindakan terdiri dari 10 pertanyaan dengan pilihan jawaban sangat setuju, setuju, jarang setuju dan tidak setuju, Responden dikatakan mengikuti jika skor yang diperoleh $\geq 80$ dan tidak mengikuti $<80$.

Uji yang digunakan adalah uji independent sampel $t$ - test. Keseluruhan pengolahan data pada penelitian ini menggunakan program Statistical Product and Service Solution (SPSS) for windows versi 24 
HASIL

Tabel 1. Karakteristik Partisipan ( $\mathrm{N}=30)$

\begin{tabular}{|c|c|c|c|c|}
\hline Distribusi Frekuensi Karakteristik & \multicolumn{2}{|c|}{ Kasus $n=15$} & \multicolumn{2}{|c|}{ Kontrol $n=15$} \\
\hline 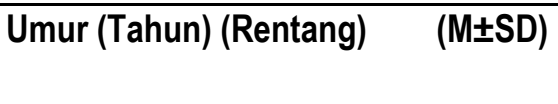 & \multicolumn{2}{|c|}{$\begin{array}{c}20-30 \\
(24.07 \pm 2.81)\end{array}$} & \multicolumn{2}{|c|}{$\begin{array}{c}20-34 \\
(25.73 \pm 4.15)\end{array}$} \\
\hline \multicolumn{5}{|l|}{ Pendidikan (n)(\%) } \\
\hline SMA & 7 & 46.7 & 5 & 33,3 \\
\hline PT & 8 & 53,3 & 10 & 66,7 \\
\hline \multicolumn{5}{|l|}{ Usia kehamilan (n)(\%) } \\
\hline Trimester II & 5 & 33,3 & 6 & 40,0 \\
\hline Trimester III & 10 & 66,7 & 9 & 60,0 \\
\hline \multicolumn{5}{|l|}{ Paritas (n)(\%) } \\
\hline Primipara & 13 & 86,7 & 12 & 80,0 \\
\hline Multipara & 2 & 13,3 & 3 & 20,0 \\
\hline Pekerjaan (n)(\%) & \multicolumn{2}{|c|}{ Kasus $n=15$} & \multicolumn{2}{|c|}{ Kontrol $n=15$} \\
\hline Bekerja & 4 & 26,7 & 4 & 26,7 \\
\hline Tidak bekerja & 11 & 73,3 & 11 & 73,3 \\
\hline
\end{tabular}

Berdasarkan tabel 1 karakteristik usia partisipan antara 20-30 tahun dan rata-rata (mean) $24.07 \pm 2.81$ pada kelompok kasus dan berusia 20-34 tahun dengan rata-rata (mean) 25.73 \pm 4.15 pada kelompok kontrol Pendidikan tertinggi pada perguruan tinggi pada kedua kelompok, dengan kehamilan pada trimester III, paritas primipara. Mayoritas parisipan dari kedua kelompok tidak bekerja.

Tabel 2. Distribusi Normalitas Data

\begin{tabular}{|c|c|c|c|}
\hline Variabel & $\rho$ Value & Distribusi Data & Pilihan Statistik \\
\hline $\begin{array}{l}\text { Kelompok Kasus } \\
\text { Pretest-postest }\end{array}$ & 0,937 & Normal & Paired $t$ test \\
\hline $\begin{array}{l}\text { Kelompok Kontrol } \\
\text { Pretest-postest }\end{array}$ & 0,297 & Normal & Paired $t$ test \\
\hline
\end{tabular}

Berdasarkan tabel 2 hasil uji normalitas didapatkan semua data terdistribusi normal, sehingga dapat dilakukan uji Paired t test. 
Tabel 3. Hasil Paired Test Kelompok Kasus dan Kelompok Kontrol

\begin{tabular}{lcccc}
\hline \multirow{2}{*}{ Variabel } & \multicolumn{2}{c}{$\begin{array}{c}\text { Kelompok Kasus (Dengan } \\
\text { Media WhatsApp) }\end{array}$} & \multicolumn{2}{c}{$\begin{array}{c}\text { Kelompok Kontrol ( Dengan } \\
\text { Media Kelas Ibu Hamil ) }\end{array}$} \\
\cline { 2 - 5 } & Mean \pm SD & $\rho$ value & Mean \pm SD & $\rho$ value \\
\hline Pre Pengetahuan & $65,60 \pm 10,09$ & 0,660 & $59,07 \pm 5,54$ & 0,588 \\
Post Pengetahuan & $76,07 \pm 8,31$ & & $79,60 \pm 7,97$ & \\
Pre Keaktifan & $81,67 \pm 5,77$ & 0,019 & - & - \\
Post Keaktifan & $90,93 \pm 4,21$ & & - & \\
Pre Keaktifan Kelas Ibu Hamil & $78,40 \pm 4,50$ & 0,424 & $74,60 \pm 5,69$ & 0,487 \\
Post Keaktifan Kelas Ibu Hamil & $87,73 \pm 6,22$ & & $79,67 \pm 4,51$ & \\
Pre Motivasi & $77,53 \pm 4,58$ & 0,0001 & $78,00 \pm 5,68$ & 0,506 \\
Post Motivasi & $87,93 \pm 4,28$ & & $85,93 \pm 4,92$ & \\
Pre Tindakan & $80,13 \pm 4,98$ & 0,725 & $85,60 \pm 4,15$ & 0,015 \\
Post Tindakan & $88,47 \pm 3,48$ & & $88,07 \pm 6,48$ & \\
\hline
\end{tabular}

Tabel 4 Analisis Bivariat Pada Kelompok Kasus dan Kontrol

\begin{tabular}{lcccc}
\hline Variabel & \multicolumn{2}{c}{$\begin{array}{c}\text { Kelompok Kasus (Dengan } \\
\text { Media Whatsapp) }\end{array}$} & \multicolumn{2}{c}{$\begin{array}{c}\text { Kelompok Kontrol ( Dengan } \\
\text { Media Kelas Ibu Hamil ) }\end{array}$} \\
\cline { 2 - 5 } & $\mathrm{t}$-test & $\rho$ value & t-test & $\rho$ value \\
\hline $\begin{array}{l}\text { Pretest - posttest } \\
\text { pengetahuan }\end{array}$ & 2,92 & 0,00 & 8,84 & 0,01 \\
$\begin{array}{l}\text { Pretest - posttest } \\
\text { keaktifan WA }\end{array}$ & 7,64 & 0,00 & 3,00 & 0,01 \\
$\begin{array}{l}\text { Pretest - posttest } \\
\text { keaktifan kelas ibu }\end{array}$ & 5,30 & 0,00 & 4,22 & 0,00 \\
$\begin{array}{l}\text { hamil } \\
\begin{array}{l}\text { Pretest - postest } \\
\text { motivasi }\end{array}\end{array}$ & 12,94 & 0,00 & 1,86 & 0,08 \\
$\begin{array}{l}\text { Pretest - posttest } \\
\text { tindakan }\end{array}$ & 5,57 & 0,00 & 8,84 & 0,01 \\
\hline
\end{tabular}

\section{PEMBAHASAN}

Hasil penelitian yang diperoleh menunjukan bahwa ada pengaruh kelas ibu hamil dan whatsapp terhadap pengetahuan, keaktifan, motivasi dan tindakan ibu hamil setelah mendapatkan intervensi berupa kelas ibu hamil dan whatsapp yang mengalami peningkatan skor pada sebelum dan sesudah dilakukan intervensi. Meskipun terjadi peningkatan skor rata - rata pengetahuan, keaktifan, motivasi dan tindakan pada ibu hamil di kelompok kontrol tetapi peningkatan tersebut lebih kecil dibandingan dari pada kelompok perlakuan. Hal ini di duga karena meskipun kelompok kontrol tidak mendapatkan informasi dari media whatsapp tetapi ibu hamil mendapatkan informasi dan edukasi seputar masalah kesehatannya pada saat melakukan pemeriksaan ANC. Sama halnya dengan beberapa hasil penelitian sebelumnya menyatakan penyampaian informasi menggunakan SMS reminder efektif untuk merubah pengetahuan, sikap, motivasi dan tindakan ibu hamil (Yani, Suriah \& Jafar, 2017; Cates, Carter-Young, Conley, \& O'Brien, 2004; Sari, Suryani, \& Handayani, 2010; Budiarni, \& Subagio, 2012).

Kelas Ibu hamil merupakan program yang bertujuan untuk meningkatkan pengetahuan dan wawasan ibu hamil. Pengetahuan ibu hamil hanya terbatas pada konseling yang diberikan bidan pada saat dilakukan pemeriksaaan, dengan danya pelaksanaan ibu hamil diharapkan ibu akan mendapatkan pengetahuan yang lebih luas dari petugas kesehatan dan adanya interaksi dari sesama ibu hamil lain (Yuliaswati 2019). 
Pemanfaatan kelas ibu hamil dan aplikasi grup pesan pintar sebagai sarana edukasi kehamilan

Penelitian ini terlihat bahwa pengetahuan pada kelompok perlakukan secara signifikan meningkat setelah mendapatkan perlakukan berupa penyampaian edukasi melalui media whatsapp . Hal ini dapat menunjukan bahwa ibu hamil pada kelompok perlakuan mempunyai kemampuan untuk mengingat informasi yang sudah disampaikan melalui whatsapp yang berkenaan dengan edukasi seputar masalah kesehatan ibu selama masa kehamilan.

Salah satu cara pemerintah untuk melakukan pendidikan kesehatan dalam bentuk penyuluhan kesehatan kepada masyarakat dan sebagai upaya untuk menurungkan AKI dan AKB diantaranya adalah melakukan kelas ibu hamil. Kelas ibu hamil menjadi sarana belajar bersama yang dilakukan pada ibu hamil yang memiliki usia kehamilan 20-23 minggu (Retnowati 2018).

Kelas ibu hamil diharapkan dapat meningkatkan pengetahuan, merubah sikap dan perilaku ibu agar memahami tentang kehamilan, perubahan tubuh dan keluhan selama kehamilan, perawatan kehamilan, persalinan, perawatan nifas, keluarga berencana pasca persalinan, penyakit menular dan akte kelahiran.

Pengetahuan merupakan suatu wahana untuk mendasari seorang berprilaku secara alamiah (Notoatmojo, 2003). Semakin tinggi pengetahuan seseorang maka untuk beradaptasi terhadap dirinya dan lingkungan inovasi yang baru maka akan semakin baik pula penerimaanya terhadap informasi yang akan diberikan petugas kesehatan sehinggah dapat ikut serta dalam kelas ibu hamil yang telah dirancang oleh pemerintah (Retnowati, \& Ully, 2018).

Mayoritas ibu memiliki tingkat pengetahuan yang baik mengenai kelas ibu hamil. Pengetahuan merupakan hasil pengindraan manusia atau hal lain terhadap objeck melalui indra yang dimilikinya, sebagian besar pengetahuan orang diperoleh dari pendengaran dan penglihatan (Notoatmodjo, 2010). Ibu yang memiliki tingkat pengetahuan baik akan semakin terbuka wawasannya sehingga akan mudah menerima halhal baru dan semakin mendorong ibu untuk lebih memahami dan ikut serta dalam kelas ibu hamil (Uddyni, MP \& Setyowati 2014).

Pada variabel keaktifan ibu hamil terlihat perbedaan yang sangat bermakna pada kedua kelompok tersebut Adanya ibu hamil yang tidak ikut serta dalam pelaksanaan kelas ibu hamil diduga adalah faktor motivasi yang menjadi penyebab utama. Motivasi itu sendiri dipengaruhi oleh banyak faktor, antara lain tingkat pendidikan dan pengetahuan, usia, status pekerjaan, paritas, dukungan suami, dan sebagainya (Indah, \& Julyarni, 2014).

Penelitian sebelumnya oleh Astuti, Sofianti \& Widyaningsih (2016) telah mengidentifikasi beberapa faktor yang mempengaruhi keikutsertaan ibu hamil dalam kelas ibu hamil. Pada penelitian ini juga terdapat beberapa faktor yang mempengaruhi rendahnya motivasi ibu hamil dalam mengikuti kelas ibu hamil yaitu : (1) kurangnya pengetahuan ibu hamil tentang manfaat mengikuti kelas ibu hamil, (2) jarak tempat tinggal dengan yang menjadi tempat penyelenggaraan kelas ibu hamil terbilang cukup jauh, (3) tidak tersedia sarana transportasi umum yang mudah diakses untuk menuju tempat penyelenggaraan kelas ibu hamil, (4) pekerjaan ibu hamil, dan (5) kurangnya dukungan suami kepada ibu hamil untuk mengikuti kelas ibu hamil (Retnowati, \& Ully, 2018).

Menurut Aribowo (2007), tinggi rendahnya motivasi ibu hamil mengikuti kelas ibu hamil dapat diukur menggunakan beberapa indikator, yaitu frekuensi keiktsertaan kelas ibu hamil, durasi dalam kegiatan kelas ibu hamil, ketabahan dan keuletan menghadapi rintangan dalam mengikuti kelas ibu hamil, usaha dan pengorbanan untuk mengikuti kelas ibu hamil, dan tingkat kualifikasi prestasi yang dihasilkan darikeikutsertaan dalam kelas ibu hamil (Retnowati, \& Ully, 2018).

Menurut penelitian sebelumnya didapatkan hasil bahwa pengetahuan dapat memberikan dampak terhadap ibu hamil dalam mengikuti suatu kegiatan. Artinya pengetahuan sangat mempengaruhi seseorang dalam melakukan tindakan terutama dalam mengikuti kelas ibu hamil (Desmariyenti, \& Hartati, 2019; Desmariyenti, Sarlis, \& Fitriani, 2018).

Sedangkan pada variabel motivasi didapatkan bahwa pada kelompok kasus terlihat perubahan sebelum dan setelah dilakukan perlakukan, yang awalnya motivasi rendah setelah dilakukan perlakuan kelas ibu hamil dan media whatsapp menjadi motivasinya tinggi sama halnya dengan kelompok kontrol terjadi perubahan motivasi dari sebelum dan setelah dilakukan kelas ibu hamil. Namun pada kelompok kasus jumlah ibu yang memiliki motivasi tinggi setelah perlakukan lebih banyak dibandingan pada kelompok kontrol. Ini diduga bahwa masih adanya ibu hamil yang memiliki faktor sikap yang intrisik seperti , kurang 
Pemanfaatan kelas ibu hamil dan aplikasi grup pesan pintar sebagai sarana edukasi kehamilan

pengetahuanya, minat, perasaan , kebutuhan, keperibadian sehingga tidak termotivasi untuk menambah wawasan tentang kelas ibu hamil.

Pada variabel tindakan, didapatkan hasil bahwa perbandingan yang diperoleh dari kelompok kasus dan kontrol sebelum dan setelah dilakukan perlakuan memperlihatkan hasil yang berbeda secara signifikan. Pada kelompok kasus ibu yang mengikuti edukasi yang disampaikan lebih tinggi setelah dilakukan perlakuan dibandingan pada kelompok kontrol masih ada yang didapatkan ibu yang tidak mengikuti eduksi yang diberikan setelah perlakuan atau bahwa tidak ada pengaruh tindakan terhadap kelas ibu hamil sebagai sarana edukasi seputar masalah kehamilan. Hal ini diduga bahwa penyampaian pesan dan informasi melalui pesan ponsel dapat mendorong perubahan tindakan ibu dalam menghadapi persalinananya. Selain itu menurut Prochaska dengan konsep The Transtheorical Model dalam Bartholomew, et al., menyatakan perubahan perilaku individu berlangsung secara bertahap sejalan dengan waktu dan perubahan perilaku terjadi dalam waktu satu bulan berikutnya (Eldredge, Markham, Ruiter, Fernández, Kok, \& Parcel, 2016).

Hasil penelitian yang telah dilakukan dengan melakukan kombinasi metode kelas ibu hamil dan pengunaan media whatsapp didapatkan bahwa responden yang terdiri dari ibu hamil pada kelompok kasus dan kontrol dinilai sangat efektif dalam merubah perilaku ibu hamil dalam berkomunikasi dan menjadikan media whatsapp sebagai sarana edukasi pembelajaran yang diukur dengan peningkatan pengetahuan, keaktifan, motivasi dan tindakan ibu setelah dilakukan perlakuan.

Penelitian yang dilakukan oleh Dwi Ajeng Winarni (2019) dengan judul pemanfaaatan media sosial dalam sosialisasi kesehatan reproduksi dan nutrisi untuk perempuan didapatkan hasil bahwa penggunaan whatsapp menjadi media yang digunakan untuk memenuhi kebutuhan informasi khususnya dalam mengakses informasi mengenai kesehatan reproduksi dan nutrisi (Widarini, 2019).

Sedangkan hasil penelitian Ibnu Zaki \& Hesti (2019) didapatkan bahwa Ada perbedaan pengetahuan gizi, asupan energi, dan protein sebelum dan sesudah edukasi gizi berbasis sosial media di perdesaan maupun perkotaan. Media sosial seperti whatsapp merupakan proses penerimaan informasi melalui infografis yang terjadi pada saat edukasi berlangsung yang memiliki keunggulan yaitu manusia cepat menangkap informasi yang disampaikan (Zaki, \& Sari, 2019).

\section{SIMPULAN}

Pada kelompok kasus didapatakan hasil variabel pengetahuan, keaktifan, motivasi dan tindakan berpengaruh terhadap pemanfaatan kelas ibu hamil dan media whatsapp.Sedangkan pada kelompok kontrol variabel tindakan tidak berpengaruh terhadap kelasibu hamil.

\section{SARAN}

Agar lebih meningkatkan kampanye tentang pentingnya peran serta ibu hamil dalam pelaksanaan kelas ibu hamil dan dapat melakukan secara rutin dengan melibatkan keluarga

\section{DAFTAR PUSTAKA}

Astuti, W. W., Sofiyanti, I., \& Widyaningsih, A. (2016). Faktor-Faktor Yang Berhubungan Dengan Keikutsertaan Mengikuti Kelas Ibu Hamil Di Puskesmas Candiroto Kabupaten Temanggung. In prosiding seminar nasional \& internasional (Vol. 1, No. 1). file:///C:/Users/asus/Downloads/2068-4265-1$\underline{\text { SM.pdf }}$

Baroroh, I., Jannah, M., \& Meikawati, P. R. (2017). Hubungan Pengetahuan Ibu Hamil Dengan Keikutsertaan Kelas Ibu Hamil Di Wilayah Kerja Puskesmas Jenggot Kota pekalongan. Siklus: Journal Research Midwifery Politeknik Tegal, 6(2).

http://ejournal.poltektegal.ac.id/index.php/siklus larticle/viewFile/579/500

Budiarni, W., \& Subagio, H. W. (2012). Hubungan pengetahuan, sikap, dan motivasi dengan kepatuhan konsumsi tablet besi folat pada ibu hamil (Doctoral dissertation, Diponegoro University).

Cahyono, A. S. (2016). Pengaruh media sosial terhadap perubahan sosial masyarakat di Indonesia. Jurnal Publiciana, 9(1), 140-157. http://jurnalunita.org/index.php/publiciana/article/download/ $\underline{79 / 73}$ 
Pemanfaatan kelas ibu hamil dan aplikasi grup pesan pintar sebagai sarana edukasi kehamilan

Cates, S. C., Carter-Young, H. L., Conley, S., \& O'Brien, B. (2004). Pregnant women and listeriosis: preferred educational messages and delivery mechanisms. Journal of nutrition education and behavior, 36(3), 121-127.

Desmariyenti, D., \& Hartati, S. (2019). Faktor Yang Berhubungan Dengan Keikutsertaan Ibu Hamil Dalam Kelas Ibu Hamil. Photon: Jurnal Sain dan Kesehatan, 9(2), 114-122. http://ejurnal.umri.ac.id/index.php/photon/article /download/1126/823

Desmariyenti, D., Sarlis, N., \& Fitriani, R. (2018). Hubungan Pengetahuan Dan Sikap Ibu Dengan Keputusan Waktu Penyapihan. Jurnal Endurance, 3(3), 500-509. http://ejournal.Ildikti10.id/index.php/endurance/a rticle/download/3141/1133

Ekadinata, N., \& Widyandana, D. (2017). Promosi kesehatan menggunakan gambar dan teks dalam aplikasi WhatsApp pada kader posbindu. Berita Kedokteran Masyarakat, 33(11), 547-552. http://jurnalunita.org/index.php/publiciana/article/download/ $\underline{79 / 73}$

Eldredge, L. K. B., Markham, C. M., Ruiter, R. A., Fernández, M. E., Kok, G., \& Parcel, G. S. (2016). Planning health promotion programs: an intervention mapping approach. John Wiley \& Sons.

Indah, S., \& Julyarni, Y. (2014). Hubungan Dukungan Suami, Motivasi lbu dan Minat Terhadap Kunjungan Kelas Ibu Hamil Di Desa Dadaprejo Sengkaling Malang. Biomed Science, 2(2), $\quad$ 40-48. file:///C:/Users/asus/Downloads/866-1599-1$\underline{\text { SM.pdf }}$

Kementerian Kesehatan Republik Indonesia. (2014). Pusat Data dan Informasi. Mother Days. Jakarta file:///C:/Users/asus/Downloads/infodatinibu.pdf

Mandiri, J. S. S. N. (2016). Sistem Informasi Pelayanan Puskesmas Berbasis Web. Indonesian Journal on Software Engineering (IJSE), 2(1). https://scholar.google.co.id/scholar?hl=id\&as_s

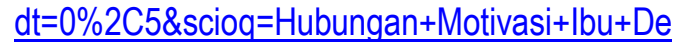
ngan+Keikutsertaan+lbu+Dalam+Kelas+lbu+H amil+Di+Wilayah+Kerja+Puskesmas+Selopam pang+Kecamatan+Selopampang+Kabupaten+ Temanggun\&q=undari\%2C+Jenie. $+2016 .+\% \mathrm{E} 2$ $\% 80 \% 9$ CSistem+Informasi+Pelayanan+Puskes mas+Berbasis+Web. $\%$ E2\%80\%9D+2\%281\%2 $9 \% 3 \mathrm{~A}+44 \% \mathrm{E} 2 \% 80 \% 9349 .+\& \mathrm{btnG}=$

Notoatmodjo, S. (2003). Pendidikan dan perilaku kesehatan. Jakarta: rineka cipta, 16, 15-49.

Notoatmodjo, S. (2010). Metodologi penelitian kesehatan.

Retnowati, Y., \& Ully, S. (2018). Analisis Motivasi Ibu Hamil Dalam Mengikuti Kelas Ibu Hamil Di Daerah Pesisir Wilayah Kerja Puskesmas Pantai Amal Kota Tarakan. Journal of Borneo Holistic Health, 1(2). http://180.250.193.171/index.php/borticalth/artic le/download/502/278

Sari, S. K., Suryani, E. S., \& Handayani, R. (2010). Hubungan konseling keluarga berencana (KB) dengan pengambilan keputusan pasangan usia subur (PUS) dalam penggunaan alat kontrasepsi. Bidan Prada: Jurnal Publikasi Kebidanan Akbid YLPP Purwokerto, 1(01).

Setyaningsih, P., \& Ersila, W. (2016). Pendampingan Kelas lbu Hamil dalam Upaya Meningkatkan Kesehatan Ibu \& Janin di Desa Kutosari Kecamatan Doro Kabupaten Pekalongan. In PROSIDING SEMINAR NASIONAL \& INTERNASIONAL (Vol. 1, No. 1). http://103.97.100.145/index.php/psn12012010/ article/viewFile/2109/2136

Simorangkir, R.O., \& Sumardiani, L. (2016). Pengaruh Kelas lbu Hamil Terhadap Pengetahuan Dan Sikap lbu Tentang Pemeriksaan Dan Perawatan Kehamilan Di Wilayah Kerja Puskesmas Batam Tahun 2016. https://docplayer.info/55065548-Pengaruhkelas-ibu-hamil-terhadap-pengetahuan-dansikap-ibu-tentang-pemeriksaan-dan-perawatankehamilan-di-wilayah-kerja-puskesmas-batamtahun-2016.html 
Pemanfaatan kelas ibu hamil dan aplikasi grup pesan pintar sebagai sarana edukasi kehamilan

Sutopo, A., Arthati, D. F., \& Rahmi, U. A. (2014). Kajian indikator sustainable development goals (SDGs). Jakarta: Badan Pusat Statistik.. https://media.neliti.com/media/publications/488 52-ID-kaijian-indikator-sustainabledevelopment-goals.pdf

Uddyani, M.P.N \& Setyowati, E.B. (2014). Tingkat Pengetahuan dan Keikutsertaan dalam Kelas lbu Hamil. https://griyahusada.id/filesharing/jurnalfiles/vol1no2/Penelitian1.5.pdf

Widarini, D. A. (2019). Pemanfaatan Media Sosial dalam Sosialisasi Kesehatan Reproduksi dan Nutrisi untuk Perempuan. Jurnal Komunikasi Pembangunan, 17(1), 92-101. http://journal.jpb.ac.id/index.php/jurnalkmp/articl e/download/26594/17169

Yani, A., Suriah, S., \& Jafar, N. (2017). Pengaruh SMS Reminder Terhadap Perilaku Ibu Hamil Mengonsumsi Tablet Fe.Media Kesehatan Masyarakat Indonesia, 13(1), 12-20. https://journal.unhas.ac.id/index.php/mkmi/articl e/download/1578/886
Yuliaswati, E \& Kamida, K. (2019). Pelaksanaan Kelas Ibu Hamil sebagai Upaya Menurunkan Angka Kematian lbu Studi Lapangan di Puskesmas Plupuh I Sragen.Jurnal IImu Kesehatan17(2):167

https://www.researchgate.net/publication/33889 3218 Pelaksanaan Kelas Ibu Hamil sebagai Upaya Menurunkan Angka Kematian Ibu St udi_Lapangan_di_Puskesmas_Plupuh_I_Srage $\underline{\mathrm{n}}$

Zaki, I., \& Sari, H. P. (2019). Edukasi gizi berbasis media sosial meningkatkan pengetahuan dan asupan energi-protein remaja putri dengan kurang energi kronik (KEK). GIZI INDONESIA, 42(2), 111-122. file:///C:/Users/asus/Downloads/469-1470-2PB\%20(1).pdf 